\title{
Kulttuuria yhteiskunnallistamassa
}

\author{
Fingerroos, Outi, Niina Koskihaara, Sanna Lillbroända-Annala ja Maija \\ Lundgren (toim.). 2017. Yhteiskuntaetnologia. Helsinki: SKS. 295 sivua.
}

\author{
Sari Tuuva-Hongisto
}

$\mathrm{E}$ tnografisesta tiedosta on tullut valtavirtaa paikallisten ja yhteisöiden arkeen vaikuttavien ilmiöiden tutkimuksessa. Yhteiskuntaetnologia-kirjan (2017) idea kumpuaa toimittajien havainnosta etnografisen tiedon kiinnostavuudesta muiden tieteenalojen tutkijoille. "Kirjan fokus on ajankohtaisessa, tällä hetkellä Suomessa eri yliopistoissa tehtävässä yhteiskuntaetnologisessa tutkimuksessa" (s.7). Kyse on siis uudesta suuntauksesta, jota kirjalla tuodaan tunnetuksi ja tunnustetuksi.

Teoksen artikkelit käsittelevät muun muassa perheenyhdistämistä, palveluja, tutkimusetiikkaa, kaupunkitutkimusta, naisten informaalia taloutta, köyhyyttä, kuntaliitoksia, maaseutututkimusta, vesistöjä sekä kielentutkimusta. Temaattinen kirjo on siis hyvin laaja ja monipuolinen. Monitieteisyyden rajapinnoilla olevia artikkeleja yhdistää yhteinen tutkimusote - yhteiskuntaetnologia.

\section{Ytimessä arkinen, kokemuksellinen ja paikallinen tieto}

Yhteiskuntaetnologian anti ja mahdollisuus ovat selvästikin sen kyvyssä tarttua ajankohtaisiin, kiinnostaviin ja tärkeisiin yhteiskunnallisiin prosesseihin sekä tarjota niihin "ihmisläheistä" ja kulttuurista näkökulmaa. Yhteiskuntaetnologit tarjoavat selityksiä, kuvailua ja ymmärrystä. Hyvänä esimerkkinä tästä Koskihaaran ja Mäkisen artikkeli "Kuntaliitos paikallisten tunteiden ja toiminnan näyttämönä". Artikkeli tarjoaa temaattisen kohdennuksen lisäksi hyvän paikannuksen yhteiskuntaetnologiselle tutkimukselle ja yhteiskunnallisen otteen jatkumolle etnologisen tutkimuksen historiassa.

Kirjan sanoma tiivistyy huomioon paikallisen tiedon merkityksestä: "Paikallinen perspektiivi on avain ymmärtää yhteisöjen selviytymistä yhä kansainvälisemmässä maailmassa, sillä tavat, joilla valtio tai muu laajempi organisaatio luo luottamusta ja varmuutta, näyttäytyvät paikallisella tasolla." (s. 15.) Yhteiskuntaetnologialle on myös olennaista kyky tarttua kysymyksiin, jotka ovat "häiritseviä ja hankalia" ja jotka mielellään "lakaistaan maton alle" ja jäävät katveeseen. Toisaalta tässä saattaa myös olla yhteiskuntaetnologian sudenkuoppa. Monesti tällaiset kysymykset jätetään mielellään analysoimatta ja nostamatta tapetille juuri siksi, ettei niitä haluta nähdä. 
Yhteiskuntaetnologinen tieto asettuukin useissa artikkeleissa vastakkaiseksi "viralliselle tiedolle", josta kokemuksellinen tuo oman näkökulmansa (s. 249). Tässä myös tulee esiin tietynlainen marginaaliin asettuminen ja viralliselle tiedolle eriävän tiedonintressin esiintulo: tutkimusta luonnehtii käytännönläheinen tiedonintressi, johon sisältyy usein myös kriittinen ote ja jopa yhteiskunnan rakenteista uutta paljastava orientaatio (s. 22). Samalla kuitenkin toivoisin, ettei kokemuksellista tietoa automaattisesti pidettäisi "vähemmän vakavasti otettavana" kuin virallista tietoa monitieteisissä ja monialaisissa yhteyksissä. Tässä yhteiskuntaetnologeilla on varmasti haastetta.

\section{Yhteiskuntaetnologit vastatuulessa}

Kokoelmassa tuodaan runsaasti esiin kuvauksia, joissa monitieteisissä hankkeissa toimivat etnologit päätyvät jonkinlaisen altavastaajan asemaan. Kirjoittajat käsittelevät artikkeleissaan sitä, millaista kritiikkiä tutkijat saavat tehdessään monitieteistä tutkimusta ja puolustellessaan tuottamansa tiedon legitiimiyttä. Kritiikissä on yleisesti kyse myös laajemmasta laadulliseen tutkimukseen sekä laadulliseen tietoon kohdistuvasta kritiikistä ja epäilystä. Samaan aikaan syvemmästä ja laadullisemmasta tiedosta ollaan kiinnostuneita, mutta samalla epäillään sen oikeutusta: kritisoidaan tutkimuksen edustavuutta tai aineiston määrällistä lukumäärää argumenteilla, jotka eivät oikeastaan ole valideja silloin kun kritisoidaan laadullista tutkimusta, etnografista tai etnologista tutkimusta.

Kirjasta paistaa turhautuneisuus, jota etnografit monitieteisissä hankkeissa kokevat, kun heidän tekemäänsä tutkimusta mitätöidään ja epäillään (erit. Hämeenahon artikkeli s. 62, myös Fingerroos). Tämä kokemus on varmasti tuttu kaikille monitieteisissä hankkeissa toimiville etnologeille, kulttuurintutkijoille, etnografeille, humanisteille tai ylipäätään laadullisen tutkimuksen tekijöille. Omaa tutkimusta sekä tutkimusotetta joutuu perustelemaan hyvin ja valitettavasti tähän ei aina riitä oman tieteenalan hyvä tuntemus. Monitieteisyys ja poikkitieteellisyys, tieteenalojen rajapinnoilla työskentely tarkoittaa sitä, että kykenee perustelemaan ja myös käyttämään itselleen vieraan tutkimusalueen keinoja osoittaakseen sen, miksi oma tutkimus on validia. Kysymys on myös siitä, että "erilaisilla tutkimusmenetelmillä tuotetaan kuitenkin vastauksia erilaisiin tutkimuskysymyksiin" (s. 63). Tavoitteena on saavuttaa syvälle kulttuuristen merkitysten tasolle menevää tietoa (s. 66).

\section{Yhteiskuntaetnologia tutkimustraditioiden jatkajana}

Useilta artikkeleilta olisi toivonut täsmällisempää paikannusta aikaisempaa tutkimukseen. Esimerkiksi "Eurajoen muuttuvia arvoja" käsittelevässä artikkelissa olisi voinut tuoda esiin vesistöihin ja luonnonympäristöihin liittyvän suhteellisen laajankin aiemman kulttuurisen tutkimusperinteen. Kokoelmassa olisi voinut myös pyrkiä luomaan yhteiskuntaetnologiselle tutkimukselle vahvempia tutkimustraditioita aikaisemmasta tutkimuksesta tai esimerkiksi jaottelemaan siinä jo selkeästi erottuvia ja näkyviä suuntauksia. Näitä olisivat voineet esimerkiksi olla juuri luontoon ja ympäristöön liittyvä tutkimus tai yhteiskunnallisten prosessien tutkimus. Myös maahanmuuton ja liikkuvuuden tutkimus tuntuvat selvästi olevan yhteiskuntaetnologisen tutkimuksen ytimessä, mistä Fingerroosin perheenyhdistämistä käsittelevä artikkeli on hyvä esimerkki.

Pyrkimys määritellä yhteiskuntaetnologia ja varata sille oma tutkimuksellinen tonttinsa tuntuu toisinaan artikkelissa jopa hivenen päälleliimatulta ja toisteiselta. Kunhan vain tarpeeksi 
monta kertaa toistaa artikkelissa sen olevan "yhteiskuntaetnologiaa" niin tutkimus epäilemättä muuttuu yhteiskuntaetnologiseksi. Myös artikkeleiden pituus ja laajuus vaihtelevat turhan paljon. Monessa tapauksessa olisin toivonut jopa väljempää kulttuurintutkimuksellista otetta, jota useimmat artikkelit myös edustivat.

Kirjassa tuodaan useasti esiin näkökulman uutuus, vaikka samanaikaisesti tunnustetaan sen olleen myös aiemman etnologisen tutkimuksen ytimessä. Onko yhteiskunnallisessa orientaatiossa lopulta mitään uutta? Kansallisten tieteiden (suomen kielen tutkimus, kotimainen kirjallisuus, kansatiede, folkloristiikka, Suomen historia, arkeologia) tehtävänä on niiden alusta asti ollut suomalaiskansallisen, eli yhteiskunnallisen projektin edistämistä. Etnologia eli kansatiede on oppiaine, jonka juuret ovat kansallisromantiikassa ja suomalaiskansallisessa talonpoikaisen elämäntavan tutkimuksessa (s. 10). Tavoitteena on ollut koota, pelastaa ja vaalia sitä tietoa, jota on olemassa menneestä talonpoikaisesta elämäntavasta. 1960-luvulta lähtien etnologian tutkimuskohteisiin on kuulunut myös sosiaalisten rakenteiden, innovaatioiden, talonpoikaiskulttuurin murroksen sekä kaupungistumisen teemoja. Etnologian yhteiskuntaan kiinnittyvien teemojen tutkimukseen löytyy siis pitkät perinteet.

Yhteiskunnallinen ja monitieteinen etnologia, etnografia ja kulttuurintutkimus tuntuvat olevan hyvin ajankohtaisia tällä hetkellä. Kiinnostavaa on esimerkiksi se, että Suomalaisen Kirjallisuuden Seura (SKS) julkaisi miltei samanaikaisesti kirjat sekä soveltavasta kulttuurintutkimuksesta (Hämeenaho, Suopajärvi ja Ylipulli 2018) että yhteiskuntaetnologiasta, jotka molemmat kumpuavat kulttuurintutkimuksen monitieteisyyden rajapinnoilta. Kertooko tämä kulttuurintutkimuksen laajemmasta muutoksesta kohti monitieteistä kulttuurintutkimusta ja yhteiskunnallisempaa otetta?

Mikä sitten näyttäytyy yhteiskuntaetnologian ja soveltavan kulttuurintutkimuksen erona? Soveltavalla kulttuurintutkimuksella on selvästi pyrkimyksenä olla mukana prosesseissa ja tuottaa tietoa, jota hyödynnetään osana tutkittavaa prosessia ja osana monitieteisiä prosesseja. Yhteiskuntaetnologia sen sijaan määrittyy enemmän sitä kautta, että pyritään ymmärtämään, analysoimaan ja kuvaamaan yhteiskunnallisia prosesseja, mutta ei välttämättä "osallistumaan" niihin vaan enemmänkin katsomaan ulkoapäin arvioiden ja säilyttämään tutkimuksellisen ja tieteellisen etäisyyden. Yhteiskuntaetnologit toivovat vaikuttavansa (s. 23), mutta eivät tee politiikka- tai toimenpidesuosituksia analyysiensä pohjalta, joita soveltavalta tutkimukselta saatetaan jopa edellyttää. Olisin toivonut, että kirja olisi ottanut kantaa vahvemmin tähän erontekoon ja rajapintaan. Tästä huolimatta teos on tärkeä avaus kohti yhä monitieteisempää ja monipuolisempaa kulttuurista tutkimusotetta, yhteiskuntaetnologiaa.

\section{Kirjallisuus}

Hämeenaho, Pilvi, Tiina Suopajärvi ja Johanna Ylipulli (toim.). 2018. Soveltava kulttuurintutkimus. Helsinki: Suomalaisen Kirjallisuuden Seura.

FT, kulttuurintutkija Sari Tuuva-Hongisto työskentelee TKI-asiantuntijana Kaakkois-Suomen ammattikorkeakoulussa, Nuorisoalan tutkimus- ja kehittämiskeskus Juveniassa. 